\title{
Some Factors which Promote and Restrict Islamization in America*
}

\author{
Akbar Muhammad**
}

Let me begin with a brief explicatory statement about the word 'Islamization.' I use this term here in reference to a two-stage process. The first stage is conversion to Islam, ${ }^{1}$ and the second is the reinforcement, strengthening or deepening of Islam in the individual. Of course, most Muslims in the world are born into a Muslim family, and thus they do not pass through the first stage, or so it would seem. But many of them do have social, intellectual and spiritual experiences which are the essence of the second stage of Islamization. An example of this would be the effects of the international phenomenon called "the resurgence of Islam". ${ }^{2}$

In America, the situation is somewhat different. Recent immigrants from Muslim societies-say during the last eighty years-and their offspring generally do not pass through the first stage per se. However, American Muslims, who are descendants of people who arrived here from Europe (European-Americans or "white Americans") and Africa (African-Americans or "black Americans") several centuries ago, passed through, in varying degrees, both stages. Now let us consider some factors which promote and restrict Islamization in America.

\footnotetext{
*This is a slightly revised version of a speech delivered by the author at The Islamic Society of Milwaukee (Wisconsin), an organizational member of the Islamic Society of North America (Plainfield. Indiana), 27 May 1984.

**Akbar Muhammad, Ph.D., is associate professor of African and Islamic History, State University of New York at Binghamton. He has written many scholarly articles on Islamic affairs. He is currently writing a biography of American Muslim pioneer Muhammad Alexander Russell Webb.

'Basing their opinion of the Qur'anic precept that Islam is the natural religion of humankind, some American Muslims object to the use of "conversion to Islam". With all due respect to this interpretation. I use the term here in its broadest meaning, which is not necessarily dissonant with their view.

2The broadened active Muslim interest in Islam, or "the resurgence of Islam", has caused many Muslims to deepen their knowledge of various aspects of its religio-social system, thereby strengthening their commitment to it as a whole.
} 
No doubt America is amongst the most tolerant countries in the world with respect to freedom of expression and religious practice. And despite this society's many democratic shortcomings and lack of will to make its practices more congruent with its ideals, America's legal guarantees of basic freedoms foster Islamization. Muslim visitors and immigrants appreciate this fact much more than many other American Muslims, whose vision is often blurred by particular inadequacies and injustices in the American system.

Theoretically, American democracy is not disturbed by, nor does it disturb much, the new adherent of Islam, provided he/she 'renders unto Caesar' that which Caesar considers his right. To be sure, there are few countries in which many thousands of people are permitted to follow openly other than the official religion or ideology of the state, to propagate it publicly, to erect places of worship and schools to teach that the standing order should be replaced by an alien one, and to build institutions to facilitate the growth and reinforcement of a foreign way of life. Further the United States' system allows foreigners and citizens to denigrate the character of foreign leaders, and to call for their forcible removal. This type of political or religious opposition is permitted in this country even when the government has no vested interest in the aims of the resident activists. Indeed, many Muslims in America believe that they enjoy more freedom of speech, assembly, and religious and ideological expression than their coreligionists and countrymen in the Muslim world.

Another factor which promotes Islamization in America is the diversity of sources of Islamic knowledge. These include public, school, college, university and some mosque libraries, and bookshops and publishing companies owned by non-Muslims and Muslims. Additionally, several international Muslim publications from Europe, Asia and Africa are available in some of the libraries, bookstores and Islamic centers in this country.

Also, there is a growing number of knowledgeable individualsMuslims and non-Muslims-some of whom teach in educational institutions and Islamic centers across the United States. Others are pursuing higher education in various fields, or are employed in a wide diversity of professional and skilled jobs; still others are imams and officials in mosques and Islamic centers.

National, regional and local meetings and conferences sponsored by various Islamic/Muslim organizations also promote Islamization, especially the second stage-that is, reinforcement. A number of nonMuslim and Muslim academic associations provide a treasure of information about Islam through their annual conferences, journals and other publications.

We should not forget that the media in this country is a source of Islamic information, and that, in some cases, it is a primary source for the first stage of Islamization-conversion. The media, which provides 
such information, consists of the non-Muslim and Muslim-owned press, radio and television programs, and documentary films. While not all of the public media is intended to impart Islamic information, it does so, and sometimes in spite of itself. Again, in some cases, the daily and weekly media have aided the first and second stages of Islamization. I dare say that there exists in this country a greater diversity in the published materials on Islam than in many Muslim countries. ${ }^{3}$

A third factor that contributes to Islamization is social contact between Muslims. Certainly, there are many cases in which friendly contact between Muslims and non-Muslims have resulted in conversion to Islam. Direct contact is definitely the most effective reinforcer of Islamization in its first and second stages. Undoubtedly, Prophet Muhammad (pbuh) appreciated this fact to the fullest extent, for the Hadith literature is replete with exhortations, commands and even admonitions relevant to social cohesion amongst Muslims. The Prophet's sayings and acts in this regard elucidate and further reinforce the injunctions and precepts contained in several Qur'anic verses.

As a student of social history, I believe that Islam would not have spread much beyond the Arabian Peninsula had it not stressed social contact and cohesion amongst the believers. The best manifestations of that social contact and cultural cross-fertilization in the early centuries of Islam is to be found in the exegetic or commentary literature on the Qur'an and the Sunna of the Prophet, as well as in the Islamic legal works of Asian and African scholars. While this kind of social and intellectual exchange contributed to the rise of schools of thought, madhahib, it also served as a sort of cement which, to a large extent, held together the fabric of the international Muslim community. It was through social intercourse and similarities in interests, especially in local areas, which substantially account for the early spread and reinforcement of Islam. To be sure, the initial spread of Islam amongst African-Americans and its reinforcement amongst some twentiethcentury immigrants are largely due to social exchange and commonality of interests.

Thus far, I have mentioned three factors which promote Islamization

\footnotetext{
${ }^{3}$ For example, the Library of Congress (Washington, D.C.) and the libraries of major American universities, particularly those that offer post-baccalaureate degrees in Islamic/Middle Eastern/Near Eastern Studies, have more diverse holdings in the Islamic disciplines/sciences than one finds in such Muslim countries as Oman, Bahrain, Libya and Somalia - to name a few. I realize that this statement may seem to be a gross exaggeration. One reason for this fact is that the United States Government and American universities have been acquiring books in the Islamic disciplines from various Asian, European and African countries for more than a century. The U.S. Government continues to do so, principally under Law P.L. 480, the Library of Congress being the initial recipient and distributor of the books to member university libraries. This does not include other direct and indirect purchases by colleges and universities.
} 
in America, namely, the existing degree of personal freedom in America, a large body of sources of Islamic knowledge and social contact amongst Muslims. Now let us turn our attention to some factors which restrict Islamization, bearing in mind that some things which are helpful may also be harmful.

Freedom of expression and assembly is a guaranteed right to those who would propagate Islam, as well as to those who would defame itdirectly or.indirectly. Between these two extremes lies a vast area which accommodates theological and political divergencies amongst Muslims, Islamic inactivity, moral laxity, and the reinforcement of ethnic or particularistic interests. Allow me to be more specific. American constitutional freedoms permit our multi-ethnic Muslim community to propagate Islam amongst non-Muslims and to reinforce it amongst believers. Yet, the Constitution equally permits internal dissension in the Muslim ranks, and gives equal opportunity of expression to divergent and peripheral Muslim views. Somewhat more importantly, American freedoms give full rein to the galloping warhorses against Islamic practices. These warhorses are exemplified in the many aspects of American society that may cause the potential convert to Islam not to embrace it, or to weaken the faith and diminish the practice of those who are Muslims. Muslim international dissension and the freedom to present the attractive but un-Islamic characteristics of American society serve to diminish the potential for conversion to Islam and its reinforcement.

The exercise of freedom of expression by non-Muslim individuals and groups in this country significantly inhibits Islamization, especially its reinforcement. Consider the following. The individual, not the family, according to some social scientists, is the basis of American society. This society encourages 'I' and 'me' perhaps more than 'we' and 'us' attitudes in the individual. The school fosters competition for grades and the favoritism of teachers. Young people are encouraged to have and express their personal opinions, and to be proud of individual achievement. The concept of having the right to hold individual opinions becomes somewhat consecrated and sacred. There is nothing inherently wrong in this. But freedom of expression confers the right to spread individual opinions and to form or join groups which share similar ideas and ideals, without much regard for the inherent merits of counter opinions. Thus begins a form of team-work for specific goals-but individualism often remains in high gear.

In American society a Muslim has several un-Islamic choices with respect to his/her opinions and behaviour. The guarantee of freedom, within the limits of American law, may therefore decrease the degree of Islamic adherence in the individual, as well as his/her loyalty to family and the Muslim community. The potential convert, often a product of American individualism, also has several choices other than Islam. And if the Islamic concepts with which the non-Muslim is presented do not 
agree with some of his/her basic ideas, then the potential for conversion is restricted.

Another restricting factor on Islamization is what may be called 'the ethnicity of Islam'. That is, in practical terms, many so-called Islamic concepts and practices which are apparent in this country are traceable to ethnic origins abroad, or to ethnic circumstances in the United States. Historically, certain Islamic schools of thought became more prevalent than others in particular ethnic groups or nationalities. For example, most Afghans are Hanafis, as are Turks, Indians, Pakistanis and Bangladeshis. Most Egyptians, Indonesians and Malaysians are Shafi 'is. Most Sudanese, Libyans, Moroccans, Tunisians, Algerians, Nigerians and Senegambians are Malikis, while the majority of Saudis are Hanbalis. Most Iranians are Shi' is. The Gulf region is heavily populated by Shi' is, Zaydis, Shafi' is and Hanafis. Indeed, different schools and subschools exist in individual countries. These differences in some areas of Islamic interpretation are accompanied by non-religious aspects of the ethnic or national culture of Muslim immigrants in America, and perhaps of their offspring. Since the individual Muslim is a composite of school of thought (often unknowingly) and an ethnic culture, he/she necessarily holds specific Islamic and ethnic views, each sometimes legitimizing the other, and both being indiscernible to the person and to those who are not sufficiently knowlegeable about Islam.

In the case of most African-American Muslims, who are erroneously referred to as "indigenous Muslims", the ethnic aspect of the religious precepts which they called Islam was obviously part of a broader African-American liberation ideology born of centuries of slavery and humiliation. The smaller number of Sunni African-Americans, who have existed since the early years of this century, also held certain antiAmerican ideas which resulted from their low social status in America. European-American Muslim converts whom I have known held tenaciously to middle-class American values and norms, though I have no reason to say that they were racialists. All Muslims in America, therefore, exhibit cultural forms which emanate from their particular social environments. While this is natural, objectively speaking, we must recognize its limiting effects on Islamization.

Let us examine this point further. The tendency of Muslims in this country is to congregate and socialize with members of their national or cultural group. Such selective fraternization, based on ethnic similarity, helps those concerned to exchange views about situations in their countries or regions of origin, and their personal or group circumstances in this country. After 'Id prayers and during 'Id celebrations and other Islamic occasions, the worshippers tend to break up into cultural/linguistic groups. This type of preferential association reinforces, first and foremost, ethnic group allegiance and affiliationroughly what Ibn Khaldun called 'asabiyya-but it does not necessarily strengthen or deepen the Islamization of the individual. Division along 
ethno-cultural lines hardly serves as an attraction to non-Muslims to embrace Islam.

Further, this kind of social division does little to relieve the tensions caused by ideological, religious and 'racial' feelings which have origins in political and cultural aspects of the motherlands. The emergence of Ayatollah Ruhallah Khomeini, the Iraq-Iran conflict and the so-called "resurgence of Islam" have affected relations between American Muslims of different national origins on the religious and social levels. Such divisions during times of crises may compound the adverse effects of social differentiation during normal times. The injection of ethnic, national and religious terms into the political conflict between Iran and Iraq reverberates in this country-for example, the claim that it is an Arab-Persian war, a "second Qadisiyya", 4 an attempt by the Shi'a to take revenge against the Sunis, the disparagement of being Arab or Iranian. These allegations punctuate the stereotypes in the cultures of the belligerents. In America, these pungent stereotypical images are added to others regarding peoples of Indian, Pakistani, Bangladeshi, Egyptian, Saudi and sub-Saharan African origin. Some of these cultural images are most degrading and may become, in themselves, factors which determine who will associate with whom. Meanwhile, one of the most effective methods of Islamization, social interaction, may be rendered largely ineffective for the many who need it.

The last restrictive factor to Islamization that I shall mention here is the seeming insufficiency of personal knowledge of Islam. I would venture to say that this factor is not limited to this country, rather it exists in other parts of the Muslim world with which I am familiar. That is, a comparative, a cross-madhhab approach to the study of Islam is lacking amongst many Muslims and non-Muslim scholars.

In traditional Muslim countries, an ordinary student might study the basic tenets of Islam, memorize several suras and verses of the Qur'an and some hadith. Additionally, certain aspects of the lives of the Prophet and his companions, including some Muslim conquests, are studied. Normally, the student acquires this information in religious studies, reading or history classes. Further knowledge about Islam is acquired from Friday and 'Id khutbas, the media and books available from popular booksellers. Therefore, upon completion of pre-university education, the acquisition of additional Islamic learning is largely voluntary and sporadic, though some national colleges and universities require an additional course or two in Islamic studies. However, my

${ }^{4}$ Q Qadisiyya' here refers to the well-known battle of that name; it occurred in Iraq in about A.D. 637. The battle is widely known as the decisive war between Muslim Arabs and Zoroastrian Persians (Iranians), after which the previously weakened Persian empire was soundly defeated. The Iraqis have officially called their present war with Iran "the second Qadisiyya". Both parties have called each other "oppressors", "racialists" and "bad Muslims". 
information indicates that much of this is partly a repetition of what was taught in the earlier years. Given the emphasis in Muslim countries on scientific, technological and vocational studies, comparatively few students attend Islamic institutions. But too many of the Islamic institutions tend to emphasize a particular madhhab or sect.

The upshot of this brief description is that a basic knowledge of Islam is acquired in school. Beyond that stage Islamic learning is usually obtained voluntarily, and it competes with the more worldly interests and aspirations of the individual. Educationally and practically, therefore, recent immigrants to this country are overwhelmingly narrowly learned in Islam. Comparatively few have Bachelor degrees in Islamic studies from their home countries or American universities, or proceed to post-graduate study in the Islamic disciplines in American universities. Those who hold degrees in non-Islamic disciplines are seldom knowledgeable about the Muslim contributions to aspects of their fields or professions.

American-born Muslims who are not recent immigrants are a particular case. The majority of them converted to Islam during their late teens or adult years. Their knowledge of Islam was usually obtained from mainly self-taught individuals who, like their students, were converts or immigrants in one of the aforementioned categories. American-born Muslims also have some basic knowledge of Islam. A good number of them, especially the imams, have some knowledge of Arabic, the Qur'an, Hadith and commentaries thereon. Still others, like immigrants of Muslim parentage, have read some of the translated writings of well-known scholars of Egypt, Pakistan, India, Iran, Nigeria, Senegal, etc. A small number of them have spent months or years studying in Muslim countries.

There are noteworthy similarities between these two major groups of American Muslims: 1) generally, both do not have a cross-madhhab knowledge of Islam, and 2) the Hanafi school of thought is the most widely followed, since a disproportionate number of immigrant Muslims are from Hanafi backgrounds, and most of the Islamic books available from Muslim booksellers were written by Hanafi authors. Consider, for example, the number of imported books from Pakistan and India alone. That is not to say that the works of Shafi'i, Shi'i and other schools are not obtainable here; indeed they are.

In several respects, life in America is confrontational for Muslims, and raises many queries in their minds. For example, to what extent can Muslims participate in sports in which much of the body is exposed, or in a sport, like boxing, which is necessarily very violent? What is the permissible extent, if any, of a relationship between members of the opposite sex? What is the extent of a husband's rights over his wife, and what are her rights over him? What are children's rights and obligations in Islam? To what extent may a Muslim participate in the political, military and economic activities of a non-Muslim coutnry? What are the 
Islamic restrictions on the normal practice of medicine, law, psychiatry, social work, secretaryship and nursing? What parts of the male body may be exposed in public? Which methods of contraception, if any, are permissible in Islam? Are homosexuality and masturbation permissible? Under what circumstances may a man marry a second, third or fourth wife? Can a woman cut her hair? Are there any circumstances in which she may function as an imam? Is the giving of one's personal or family name to an adopted child permissible? If a woman applied her makeup in a state of ritual purity, and later became ritually impure through urination, must she remove her makeup when performing ablution? Which laboratory experiments are not permitted to be performed by a Muslim student or scientist? Is it permissible for one to donate a member of one's body to be used by another person, Muslim or non-Muslim, or to donate one's corpse for the advancement of science? Can an American Muslim convert who is named in his/her nonMuslim parent's will inherit the property of the deceased? Can a Muslim husband inherit from his non-Muslim wife?

I randomly chose these questions. Some of us probably think that we know the answers, but might be surprised to find other persons who may have different answers based on seemingly equally valid evidence from the large corpus of Islamic legal material, including different commentaries on the Qur'an and the Sunna. The responses which many of us would give would be those of particular madhhabs or scholars. Unfortunately, some individuals would engage in the frivolity of offering purely personal opinion alleging that they are shar $i$ law.

Clearly, such questions suggest the need for a cross-madhhab and an open approach to Islam. We must know that no one Sunni or Shi'i school has all the answers which may be required by American Muslims, or for that matter, by Muslims anywhere in the modern world. Indeed, our inability to give proper answers to these and other questions will indicate our lack of knowledge of Islam, and will restrict our Islamization. Potential American converts may hesitate to embrace Islam, and the questioning mind of the Muslim may decide that Islam is unsuitable to life in this age of social freedom and intellectual inquiry and curiosity.

Yes, in my opinion, the Islamization of Muslims is directly related to their knowledge of Islam. If we assert that "Islam is suitable for all times and places", then we must defend this claim and demonstrate the truth of it. And I believe that we must begin by reinforcing our own stages of Islamization by dealing effectively with the factors which restrict it. Then, perhaps, we will be more successful in our efforts to help in effecting the first stage in others.

The existing freedoms in America must be used more effectively to the advantage of Muslims. Muslims should use these freedoms, individually 
and collectively, to speak out against injustices everywhere-in this country and abroad. They must give at least moral support to just causes in this country and abroad. The Islamic injunction, "Give to every person his/her right," is not limited to Muslims, and the order to "command the good and to forbid the evil" is not necessarily limited to the Muslim community. Islamic centers and organizations should make one or more to their members or officers responsible for following community, national and international news with a view to making a collective decision as to which events and causes should be addressed and supported.

If the estimate that there are more than three million Muslims in the United States is correct, then we have more Muslims here than there are in some Muslim countries. With proper organization we could form a national voting bloc and seriously affect some local and regional elections. We could petition the national Muslim community.

With respect to what I called 'the ethnicity of Islam', we must be more tolerant of Islamic opinions and practices other than those with which we are familiar. We must recognize that Islam, in its totality, is a somewhat flexible system of laws and ethnics, and that the only absolute is Allah Most High. We must recognize that everything in Islam is neither wajib (obligatory) nor haram (prohibited), but rather that these are simply extremes between which fall most of the acts of humankind. Since when did the legal classifications of human acts known as al-mandub (recommended), al-ja'iz or al-mubah (permissible), almustahabb (commendable) and al-makruh (reprehensible) disappear from the corpus of Islamic law?

With the highest respect for all, no particular madhhab should govern this part of the Muslim community; nor should we be dependent exclusively on the thought of Ibn Taymiyya, Ja'far as-Sadiq, al-Ghazali, Usuman dan Fodio ('Uthman ibn Fudi), Hasan al-Banna, Sayyid Qutb, Malik Sy, Abul A'la alMawdudi and the contemporary imams here and in the Muslim world. This part of the international Muslim community must not be fertile ground for the extension of the old hostilities between Sunnis and Shi'is, Iranians and Arabs nor any of the negative ethnic stereotypes; rather we must be an example of the brotherhood of Islam. We must find ways to cooperate and pull together, not to divide ourselves along madhhab, sectarian and ethnic lines. Did not Allah say, "There is no compulsion in religion"? Did not the Prophet say, "The best course is the middle one", and did not the great imams agree that all of them were correct in their interpretations which were based on a wide range of evidence?

American Muslims should take advantage of the great quantity and diversity of Islamic sources in this country. We must use the library collections and patronize Muslim and non-Muslim bookshops. We must subscribe, as individuals and centers, to Muslim newspapers and other publications available in this country. And Muslim publications, as well 
as the curricula of Muslim schools and colleges, must become representative of the international Muslim community, historically and in the present.

Finally, I believe that these steps will serve the process of Islamization in America in both its stages-conversion and reinforcement. While we must work toward converting non-Muslims, we are obliged to deepen our own knowledge of Islam in its totality.

Wa l-lahu waliyyu t-tawfiq. 